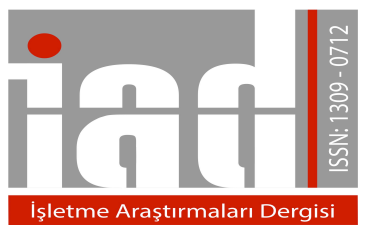

Journal Of

Business Research

Turk

www.isarder.org

\title{
The Buffering Role of Social Support on the Relationship between Job Stress and Intention to Leave ${ }^{12}$
}

\author{
Özlem SERTEL BERK \\ Istanbul University, Faculty of Letters, \\ Department of Psychology \\ Istanbul, Turkey \\ orcid.org/000-0002-3045-3903 \\ osberk@istanbul.edu.tr
}

\author{
İlknur ÖZALP TÜRETGEN \\ Istanbul University, Faculty of Letters, \\ Department of Psychology \\ Istanbul, Turkey \\ orcid.org/0000-0001-8057-2284 \\ ilknuroz@istanbul.edu.tr
}

\author{
Ece YETISŞEN SUN \\ Borusan Holding \\ Human Resources and Training Department \\ Istanbul, Turkey \\ orcid.org/0000-0002-2378-9513 \\ eyetisen@,borusan.com
}

\begin{abstract}
This study aimed to test the buffering role of social support on the relationship between job stress and intention to leave through investigating different aspects of job stressors and support sources. Participants were 116 white-collar employees from various sectors in Turkey. The results indicate that supervisor support has reverse buffering effects on the relationship between "role and work overload" and "role insufficiency" with "intention to leave." Also, coworker support has a reverse buffering effect on the relationship between "role and work overload" and "intention to leave." This study is important since it demonstrates that the moderating role of social support may vary for distinct job stressors.
\end{abstract}

Keywords: social support; job stress; intention to leave; buffering effect; reverse buffering effect

\footnotetext{
${ }^{1}$ This work was supported by the Research Fund of Istanbul University (Project No. UDP-5882), and a part of this study was presented at the $9^{\text {th. }}$ Conference of the European Academy of Occupational Health Psychology in 29-31 March 2010, in Rome, Italy.

2 A part of the data of this study came from the third author's MA thesis completed at Istanbul University and chaired by the first and second authors.
} 


\section{Introduction}

To date, job stress has been studied as a stimulus (environmental demands), as a response (reactions of the individuals to demands), or as an interaction between demands and responses (Beehr, 1976). In recent years, a successor to the interactional model, a transactional model of stress has been proposed defining job stress as a transaction between the individual and the environment in which an individual's continual cognitive evaluation of the environment takes place (Lazarus, 1991). Furthermore, researchers have emphasized that contemporary research on job stress should adopt the transactional approach since it provides the opportunity to picture the dynamics of the entire process (e.g., Hurrell, Nelson, \& Simmons, 1998).

Research in the job stress literature indicates that stressors tend not only to affect individual physical and mental health (e.g., Siu, Cooper, \& Donald, 1997) but also affect the organization the individual is working for through behavioral outcomes, such as in performance or counterproductive work behaviors, or through attitude in job satisfaction or organizational commitment (Jamal, 2005, 2007; Netemeyer, Johnston, \& Burton, 1990).

However, the relationship between the stressors and the strains can be alleviated by various individual or situational variables. For example, the Demand-Control Model (Karasek, 1979) mentions that control buffers strain caused by job demands. This model is then expanded by the integration of social support in the model (Johnson \& Hall, 1988). Furthermore, the Effort-Reward Imbalance Model emphasizes that the imbalance leads to strain and that overcommitment moderates this relationship (Siegrist, 1996). According to the Demand-Resources Model (Demerouti, Bakker, Nachreiner, \& Schaufeli, 2001), which is more comprehensive than the Demand-Control Model, there exist specific risk factors for every job, and it has been suggested that these factors can be classified into two categories: job demands and job resources. Both demands and resources denote the physical, psychological, social, and organizational aspects of the job. As resources necessitate psychological effort or skills, these efforts or skills result in various physical or psychological complaints. On the other hand, job resources are functional in terms of reaching job purposes: they reduce job demands and the resulting complaints and finally prompt personal development, learning, and improvement. One of these most important resources is social support, and, according to the model, it is expected that strains will be less remarkable for those who receive support (Bakker \& Demerouti, 2007).

One of the strains due to demands is intention to leave. However, the studies in this field concerning the relationship between job stress and intention to leave have given somewhat contradictory results (e.g., Huang, 2005; Leong, Furnham, \& Cooper, 1996). One explanation for this, according to Demand-Resources Model, might be the probable salience of moderating variables that can alleviate the adverse effects of job stressors on intention to leave, such as social support. There have been very few studies investigating the role of social support on the stressor-intention to leave relationship, however, and even their results are inconsistent (e.g., Kim \& Stoner, 2008; Nissly, Mor Barak, \& Levin, 2005). When looking further at these studies, several issues can be mentioned. First of all, these studies do not feature different dimensions of job stressors and social support simultaneously. Furthermore, in these studies, the job stress construct is measured as perceived stress. Vagg and Spielberger (1999), however, recommended 
that job stress should not just be examined on the basis of perception or frequency alone but rather that these should be combined in an appraisal that constitutes the interaction of the dimensions of both frequency and discomfort. Moreover, the samples of these studies constituted employees from social services and education. To fill in these gaps, the present study first of all investigated social support in terms of work (supervisor and coworker) and out of work support sources. Secondly, we examined job stressors using the Job Stressor Appraisal Scale (Özalp Türetgen, Sertel Berk, Basbug, \& Unsal, 2012), developed in line with Vagg and Spielberger's suggestions, which measures five distinct job stressors: "work and role overload", "organizational norms and practices", "insecure relationships", "role insufficiency", and "physical work demands". Finally, the role of the sources of social support in the relationship between the five appraised job stressors and intention to leave were tested on a sample of employees working in various sectors.

\section{Intention to Leave and Social Support in the Job Stress Process}

Intention to leave is considered by Mobley (1977) as a rational step that follows job dissatisfaction in the process of job withdrawal that may result in quitting the job. While job dissatisfaction is viewed as a substantial reason for intention to leave (Hellman, 1997), quitting a job is viewed as the most significant outcome within this process; however, it is also suggested that this intention may be affected by certain attitudes, such as job satisfaction and organizational commitment (Calisir, Gumussoy, \& Iskin, 2011), as well as perceptual variables like the presence of alternatives and the labor market situation (Carsten \& Spector, 1987; Michaels \& Spector, 1982; Mobley, Griffeth, Hand, \& Meglino, 1979).

Several studies have shown a moderate relationship between job stress and intention to leave (e.g., Allisey, Noblet, Lamontagne, \& Houdmont, 2013; Duraisingam, Pidd, \& Roche, 2009). Studies that examine this relationship in detail reveal the mediating effects on these two variables of various attitudes, including job satisfaction (Jou, Kuo, \& Tang, 2013; Rasch \& Harrell, 1989; Simmons, Cochran, \& Blount, 1997), organizational commitment (Antón, 2009), and occupational commitment (Klassen \& Chiu, 2011).

Nonetheless, there is evidence for a lack of relationship between job stress and intention to leave (Leong et al., 1996). Such contradictory findings may stem not only from the mediating effects but also from miscellaneous individuals (Chiu, Chien, Lin, \& Hsiao, 2005; Shader, Broome, Broome, West, \& Nash, 2001) or situational (Pomaki, DeLongis, Frey, Short, \& Woehrle, 2010) moderating variables. One such variable is social support, defined as supportive interaction or give-and-take within an individual's formal or informal affairs (Thoits, 1982). Social support can be provided from two different sources: support received from work and support received out of work, although some authors employ three categories - support received from the employee's manager (supervisor), from coworkers, and from non-job sources (Kaufmann \& Beehr, 1986).

Social support is considered to be a variable that can diminish the negative effects of job stress, and for this reason its effects as a buffering variable have been tested in the job stress process (e.g., Chiu, Yeh, \& Huang, 2015; Parkes, Mendham, \& von Rabenau, 1994; Schreurs, Hetty van Emmerik, Günter, \& Germeys, 2012; Viswesvaran, Sanchez, \& Fisher, 1999). However, there are studies that do not support this buffering 
hypothesis (e.g., Beehr, Jex, Stacy, \& Murray, 2000; Ko \& Yom, 2003; Rahim, 1997); while social support is sometimes observed as having a buffering effect on certain strains, but not for others. For instance, some studies have indicated that social support has a buffering effect when the strains concern mental and physical health, although this has not been demonstrated if the strains are job related (Jamal, 2013; LaRocco, House, \& French, 1980). In another study, such an impact was shown in role performance but not in extra-role performance (Schreurs et al., 2012).

Another factor that can play a part in contradictory findings is related to the source of social support, that is, who provides the social support. In relevant literature, it can be seen that the buffering role of social support is reported only for some sources but not others (Dormann \& Zapf, 1999; Leather, Lawrence, Beale, Cox, \& Dickson, 1998). In general, while sources like work-related coworkers or supervisors support the existence of a buffering effect (Abdel-Halim, 1982; Reininghaus, Craig, Gournay, Hopkinson, \& Carson, 2007; Terry, Nielsen, \& Perchard, 1993; Vermeulen \& Mustard, 2000), support received from out of work does not seem to diminish the adverse effects of job stress (Leather et al., 1998). Equally, the same support source can result in varying effects on the relationship between stressors and strains, depending on the types of stressors and strains. For example, supervisor support has been found to have both no buffering and a reverse buffering role, according to the stressor type (Ismail, Suhaimi, Bakar, \& Alam, 2013). In fact, as Cohen and Wills (1985) mentioned, in order to observe a buffering effect, there should be a match between the type of social support and the stressor. In conclusion, the buffering effect of social support on the relationship between stressors and strains seems to vary as a function of the type of variable under investigation.

On the other hand, a limited number of studies testing the buffering effect of social support in the job stress process have considered intention to leave as a dependent variable. These studies have presented a similar picture to that discussed above: for some, a buffering effect is supported, and for others not. For example, Pomaki et al. (2010) reported that social support received from coworkers weakens the inverse effect of workload on intention to leave in a group of apprentice teachers, while Kim and Stoner (2008) found a stronger correlation between role stressors and intention to leave in the condition of work-related low social support. However, Nissly et al. (2005) could not demonstrate a buffering effect on the relationship between organizational stress and intention to leave for either work-related or out-of-work social support, although they did observe a direct effect for social support received from work- a similar finding to that announced by Gray and Muramatsu (2013). While both of these studies show that receiving social support directly decreases intention to leave, Beehr, Bowling, and Bennett's (2010) study showed a negative impact of social support on intention to leave when the support is received from coworkers. This finding indicates that social support may sometimes have detrimental effects.

To summarize, a few studies examining the influence of social support on the relationship between job stress and intention to leave have either focused on work overload (Pomaki et al., 2010) or role stressors (Kim \& Stoner, 2008) as specific job stressors; but others have investigated global job stress (Gray \& Muramatsu, 2013; Nissly et al., 2005). The most striking feature of these studies is that only one has investigated this relationship with respect to various sources of (work and out-of-work) social support (Nissly et al., 2005); others have examined the effects of only work- 
related social support (supervisor and coworker) (Gray \& Muramatsu, 2013; Kim \& Stoner, 2008) or only coworker support (Pomaki et al., 2010). Additionally, some have demonstrated a buffering effect (Kim \& Stoner, 2008; Pomaki et al., 2010), while others have not (Gray \& Muramatsu, 2013; Nissly et al., 2005). With respect to these results we investigated whether the expectation that the effect of work and role stressors on intention to leave will be buffered by work-related social support (Kim \& Stoner, 2008; Pomaki et al., 2010) but not by support received from out of work (Nissly et al., 2005), and whether this is valid for other sources of job stressors as well. Therefore, we hypothesize that:

H1: The relationship between work and role overload and intention to leave will be buffered by supervisor social support.

H2: The relationship between work and role overload and intention to leave will be buffered by coworker social support.

Furthermore, previous studies have only investigated job stressors as a role stressor and work overload or global job stress. However, as Cohen and Wills (1985) proposed, there should be a match between the type of stressor and social support in order to observe a buffering effect. Thus, to fully comprehend the process of job stress in relation to social support and intention to leave, this study investigates other job stressors in addition to work and role overload and explores whether the same relational patterns we hypothesized above can be observed for stressors of organizational norms and practices, insecure relationships, role insufficiency, and physical work demands.

\section{Method}

\section{Participants}

The participants comprised sample volunteer white-collar employees from different regions of Turkey, working at various companies in different sectors of a holding company. The questionnaires were sent to a total of 233 employees, and 116 replied, with a return rate of $49.8 \%$. Their mean age was $34.7(\mathrm{SD}=7.4)$; males comprised $67.2 \%, 60.3 \%$ were married, and almost $90 \%$ had at least a graduate degree. The tenure was $1-5$ years for $44 \%$ of the sample. For almost $53 \%$ of the participants, work experience was more than ten years

\section{Materials}

Job Stressor Appraisal Scale (JSAS). This scale is one of the questionnaires of the Job Stress Battery (JSB) (Özalp Türetgen et al, 2012). With 43 items related to different sources of job stress, this assesses both frequency (frequency of exposure to the source presented in the item) on a five-point Likert-type scale ranging from "never" to "always" and the intensity (extent of discomfort experienced when exposed to that source) on a ten-point Likert-type scale ranging from "nothing" to "a lot." For each item, frequency (five-point) and intensity (ten-point) scores are multiplied and summed in order to calculate the stress appraisal score. Higher scores indicate higher levels of job stress.

The scale has a five-factor structure ("Organizational Norms and Practices", "Role and Work Overload", "Insecure Relationships", "Role Insufficiency", and "Physical Work Demands"). Cronbach's alpha values were between .66 and .90 for the original 
version, and $.90, .88, .82, .83$, and .59 , for each of the five factors, respectively, in this study.

Social Support Scale. As another scale of the JSB, this 15 -item scale measures social support through three distinct factors: support received from supervisors, from coworkers at work, and from family members or friends out of work (Sertel Berk, Özalp Türetgen, Unsal, \& Basbug, 2010a), each on a five-point Likert-type scale ranging from "does not apply to me at all" to "it completely applies to me." Higher scores indicate higher levels of social support. The original version's convergent validity coefficients varied between .17 and .49. Cronbach's alpha values for the three factors as listed were between .80 and .87 for the original version. For this study, the values were $.83, .86$, and .80 , respectively, and .87 for the total scale.

Intention to Leave Scale. In order to measure the construct, we specifically used the Intention to Leave Scale of the JSB job-strain questionnaire, which also includes questionnaires on job satisfaction, job performance, and affective commitment to the organization (Sertel Berk, Özalp Türetgen, Unsal, \& Basbug, 2010b). This scale comprises three items aimed at assessing whether the individual intends to look for another job and wishes to work in his/her workplace in the future on a five-point Likerttype scale ranging from "not appropriate for me" to "completely appropriate for me." The original study validated a four-factor structure indicating the dimensions denoted above, and the scale convergent validity coefficient was .44. Cronbach's alpha value was .73 for both the original and for this study.

\section{Procedure}

All the questionnaires of the study were e-mailed to a total of 233 employees by the HR department of the organizations that gave permission for this study. The instructions sent in the mail specifically emphasized the complete independence of the study from and inaccessibility of responses to other members of their organizations. For the purpose of further confidentiality, even though the questionnaires were e-mailed, all the forms were filled out by paper \& pencil. Respondents were also asked not to disclose information about their identity. A final total of 116 replied, posting their responses to the researchers.

\section{Results}

Initially, two distinct analyses were conducted to control for the common method variance as the data were gathered from self-report questionnaires using a crosssectional design. Harman's one-factor test technique was firstly used (Podsakoff, MacKenzie, \& Podsakoff, 2012). In this technique, all of the item responses in all the study scales are entered into an exploratory factor analysis using an unrotated principal components method. This preliminary analysis yielded a 16-factor structure of eigenvalues greater than 1 with the first factor explaining almost $21 \%$ of the total variance. Thus the majority of the variance could not be attributed to a single factor. Then, a confirmatory factor analysis was performed where all variables were entered as indicators of a single latent variable vs. the indicators of three distinct major variables of job stress, social support, and intention to leave. This three-factor model demonstrated better fit indices than the single-factor model, with a significant chi-square difference test $\left(X_{(3)}^{2}=433.19, p<.001\right)$. Taken together, these findings indicate that common 
method variance does not substantially influence the validity of the statistical tests employed for our hypothesis.

Descriptive statistics and Cronbach's alpha coefficients of and Pearson correlation values between scale scores and intention to leave for each type of job stressor and social support are presented in Table 1. Looking at the correlations of the variables in the study with intention to leave, it can be seen that the Pearson coefficients of intention to leave with all the job stressors were significant, except for physical job demands and social support sources. None of the relationships concerning social support from out-ofwork with job stressors were significant, whereas social support received from work (both coworker and supervisor support) yielded varying degrees and strength of correlations with respect to the type of job stressor.

Table 1: Descriptive statistics of and inter-correlations between the variables of the study $(n=116)$

\begin{tabular}{|c|c|c|c|c|c|c|c|c|c|c|c|}
\hline & $M$ & $S D$ & 1 & 2 & 3 & 4 & 5 & 6 & 7 & 8 & 9 \\
\hline $\begin{array}{l}1 \text { JSAS- } \\
\text { Organizational } \\
\text { Norms and Practices }\end{array}$ & 8.6 & 5.6 & (.90) & $.71 * * *$ & $.47 * * *$ & $.55 * * *$ & $.35 * * *$ & .04 & $-.32 * *$ & -.01 & $.40 * *$ \\
\hline $\begin{array}{l}2 \text { JSAS-Role and } \\
\text { Work Load }\end{array}$ & 7.8 & 6.2 & & $(.88)$ & $.26^{* *}$ & $.48 * * *$ & $.31 * * *$ & .00 & -.17 & .08 & $.27 * *$ \\
\hline $\begin{array}{l}3 \text { JSAS-Insecure } \\
\text { Relationships }\end{array}$ & 3.3 & 3.6 & & & $(.82)$ & $.28 * *$ & $.19^{*}$ & -.06 & $-.33 * * *$ & $-.30 * * *$ & $.25 * *$ \\
\hline $\begin{array}{l}4 \text { JSAS-Role } \\
\text { Insufficiency }\end{array}$ & 7.0 & 7.6 & & & & $(.83)$ & .18 & .05 & -.17 & -.02 & $.49 * * *$ \\
\hline $\begin{array}{l}5 \text { JSAS-Physical } \\
\text { Work Demands }\end{array}$ & 3.1 & 5.1 & & & & & $(.59)$ & -.02 & $-.19 *$ & -.07 & .12 \\
\hline $\begin{array}{l}6 \text { Social Support - } \\
\text { Out of Work }\end{array}$ & 3.8 & 0.7 & & & & & & $(.79)$ & $.33 * * *$ & $.48 * * *$ & .12 \\
\hline $\begin{array}{l}7 \text { Social Support - } \\
\text { Supervisor }\end{array}$ & 3.5 & 0.9 & & & & & & & $(.84)$ & $.43 * * *$ & -.18 \\
\hline $\begin{array}{l}8 \text { Social Support- } \\
\text { Coworker }\end{array}$ & 3.3 & 0.9 & & & & & & & & $(.83)$ & -.05 \\
\hline 9 Intention to Leave & 6.8 & 2.6 & & & & & & & & & $(.71)$ \\
\hline
\end{tabular}

Note. ${ }^{*} p<.05, * * p<.01, * * * p<.001$. The values in the parentheses are the Cronbach's Alpha coefficients.

To test the role of different sources of social support on the relationship between stressors and intention to leave, four distinct hierarchical linear moderating regression analyses were conducted. For each analysis, one of the four types of job stressor (i.e., one of "organizational norms and practices", "role and work overload", "insecure relationships", or "role insufficiency") was entered in the first block, all three sources of social support (out of work, supervisor, and coworker) were entered as moderators in the second block, and the products of the relevant job stressor and each source of social support were entered as interaction effects in the third block; these were all regressed 
upon intention to leave. Since physical work demands were found to be unrelated to intention to leave, that factor was excluded from the rest of the analysis. The results of each analysis are summarized in Table 2.

Table 2: Hierarchical Linear Regression Analysis Results for the role of social support on the relationship between job stress and intention to leave

\begin{tabular}{lcc|ccc}
\hline Blocks & $\beta$ & $\Delta \mathrm{R}^{2}$ & & $\beta$ & $\Delta \mathrm{R}^{2}$ \\
\hline Organizational Norms and Practices & & & Role and Work Overload & \\
\hline Block 1: Main effect (a) & $.352^{* * *}$ & $.156^{* * *}$ & Block 1: Main effect (a) & $.179^{*}$ & $.072^{* *}$ \\
Block 2: SS -Out of Work (b) & $.217^{*}$ & .027 & Block 2: SS -Out of Work (b) & .181 & .056 \\
SS -Supervisor (c) & -.140 & & SS -Supervisor (c) & $.206^{*}$ & \\
SS-Coworker (d) & -.112 & & SS-Coworker (d) & .058 & \\
Block 3: a X b & -.093 & $.063^{*}$ & Block 3: a X b & .082 & $.092^{* *}$ \\
a X c & .201 & & a X c & $.196^{*}$ & \\
a X d & .120 & & a X d & $.212^{*}$ & \\
\hline Insecure Relationships & & & Role Insufficiency & & \\
\hline Block 1: Main effect (a) & $.316^{*}$ & $.062^{* *}$ & Block 1: Main effect (a) & $.432^{* * *}$ & $.242^{* * *}$ \\
Block 2: SS -Out of Work (b) & .190 & .042 & Block 2: SS -Out of Work (b) & $.210^{*}$ & .031 \\
SS -Supervisor (c) & -.126 & & SS -Supervisor (c) & .167 & \\
SS-Coworker (d) & -.024 & & SS-Coworker (d) & .059 & \\
Block 3: a X b & -.085 & .018 & Block 3: a X b & .008 & .044 \\
a X c & .148 & & a X c & $.220^{*}$ & \\
a X d & .009 & & a X d & .018 & \\
\hline
\end{tabular}

Note: Scale scores are standardized before the analysis. The standardized $\beta$ coefficients are those obtained at the third block. $\Delta \mathrm{R}^{2}$ values are recruited from step 1 for job stressors, step 2 for social support sources and step 3 for interaction effects. SS= Social Support.

$* p<.05, * * p<.01, * * * p<.001$.

As can be seen in Table 2, all job stress factors significantly predicted intention to leave. In terms of variances explained, insecure relationships had the lowest predictive value, while the most powerful predictor was role insufficiency.

As presented in Table 2, social support received from out of work did not buffer the negative effects of job stress on intention to leave for any type of job stressor. However, social support received from the supervisor was observed to moderate the relationship of "role and work overload" and "role insufficiency" with intention to leave. On the other hand, for each of these, the relationship between job stressors and intention to leave was stronger for high than for low social support received from the supervisor, indicating a reverse buffering effect (see Figure 1a and Figure 1b, respectively). Simple slope analysis (Aiken \& West, 1991) also revealed that for high level of supervisor social support there was a significant relationship between intention to leave and role and work overload $(\mathrm{b}=.360, \mathrm{t}=3.043, \mathrm{p}<.01)$, and role insufficiency 
$(\mathrm{b}=.649, \mathrm{t}=5.692, \mathrm{p}<.001)$; and it was insignificant for low level of supervisor support $(\mathrm{b}=-.002, \mathrm{t}=-.015, \mathrm{p}>.05 ; \mathrm{b}=.215, \mathrm{t}=1.649, \mathrm{p}>.05$, respectively). The result referring to the reverse buffering effect of supervisor support on the relationship between work and role overload and intention to leave is contrary to H1 where buffering rather than a reverse buffering effect was expected.

Table 2 shows that only the relationship between role and work overload and intention to leave was moderated by social support received from coworkers. However, as can be seen in Figure 1c, social support received from coworkers also had a reverse buffering effect on that relationship, which contradicts H2. This means for those employees who received high social support from their coworkers, the inverse effects of role and work overload on intention to leave tended to increase. According to simple slope analysis, there was a significant relationship between intention to leave and role and work overload for a high level of coworker support $(\mathrm{b}=.388, \mathrm{t}=3.067, p<.01)$. However, for low level of coworker support, this relationship was insignificant $(b=-$ $.030, \mathrm{t}=-.212, p>.05)$.

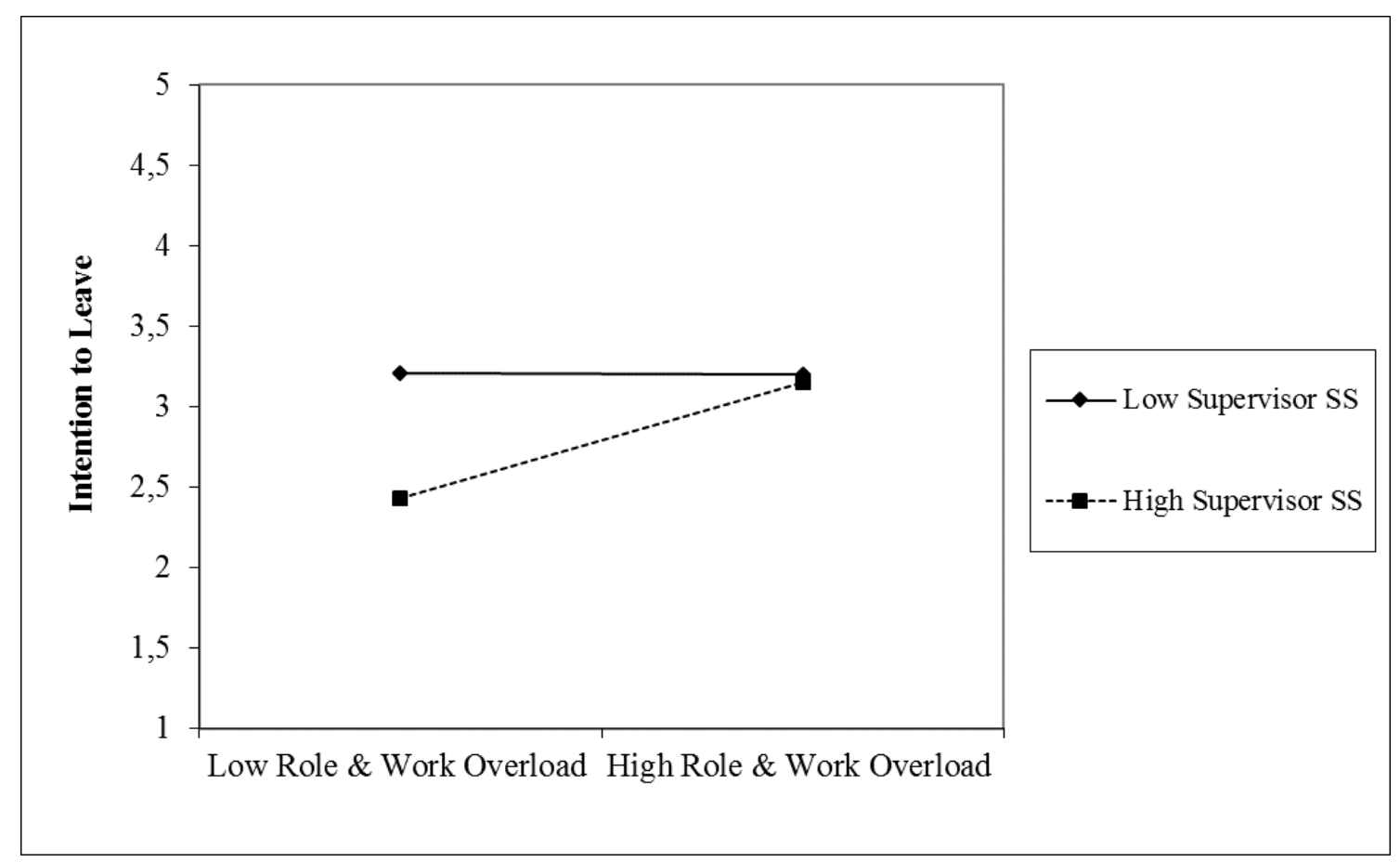

Figure 1a. The Significant Moderating Effect of Supervisor Social Support on the Relationship b/w Role and Work Overload and Intention to Leave 
Ö. Sertel Berk - İ. Özalp Türetgen - E. Yetişen Sun 9/3 (2017) 213-230

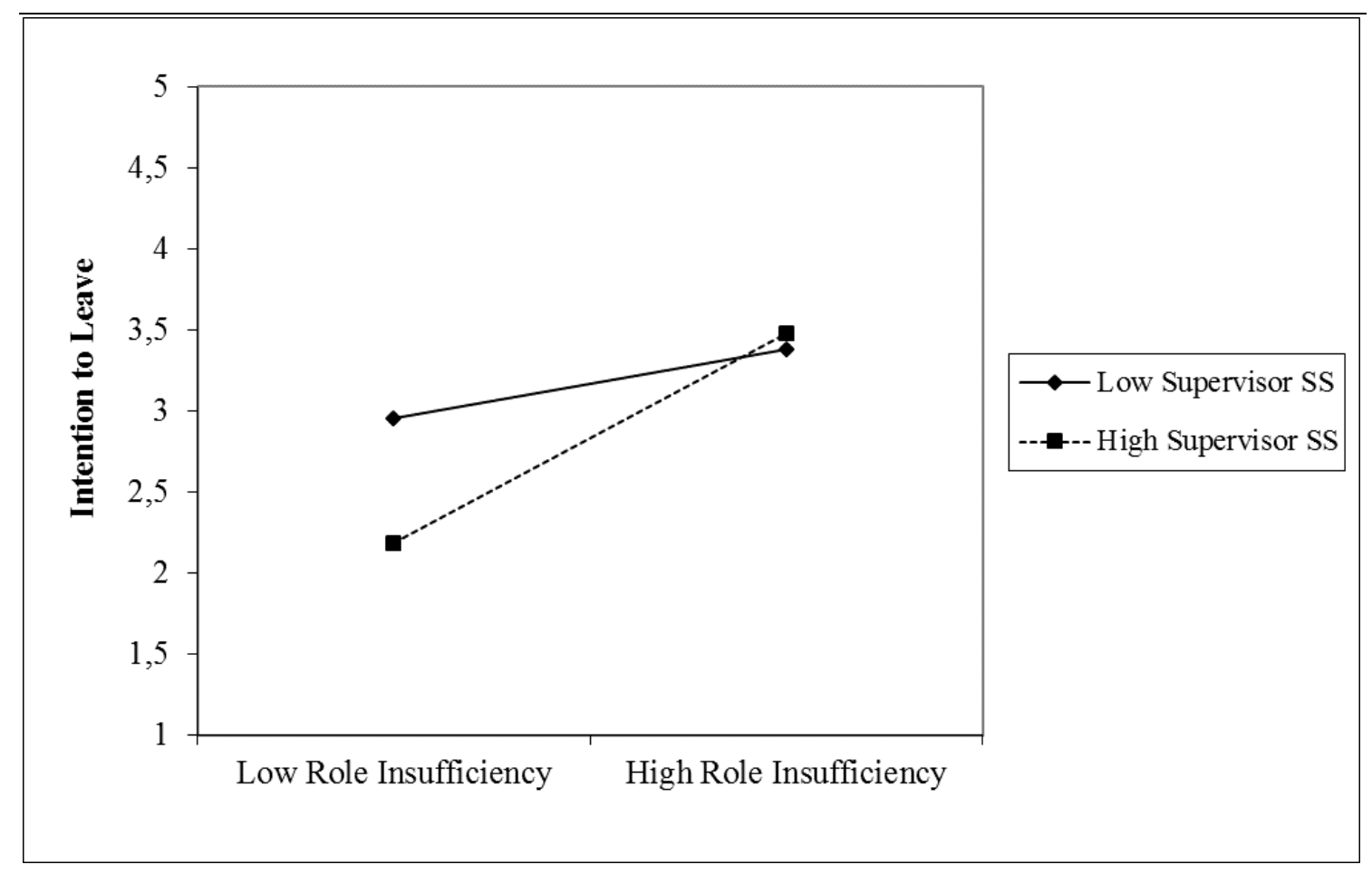

Figure 1b. The Significant Moderating Effect of Supervisor Social Support on the Relationship b/w Role Insufficiency and Intention to Leave.

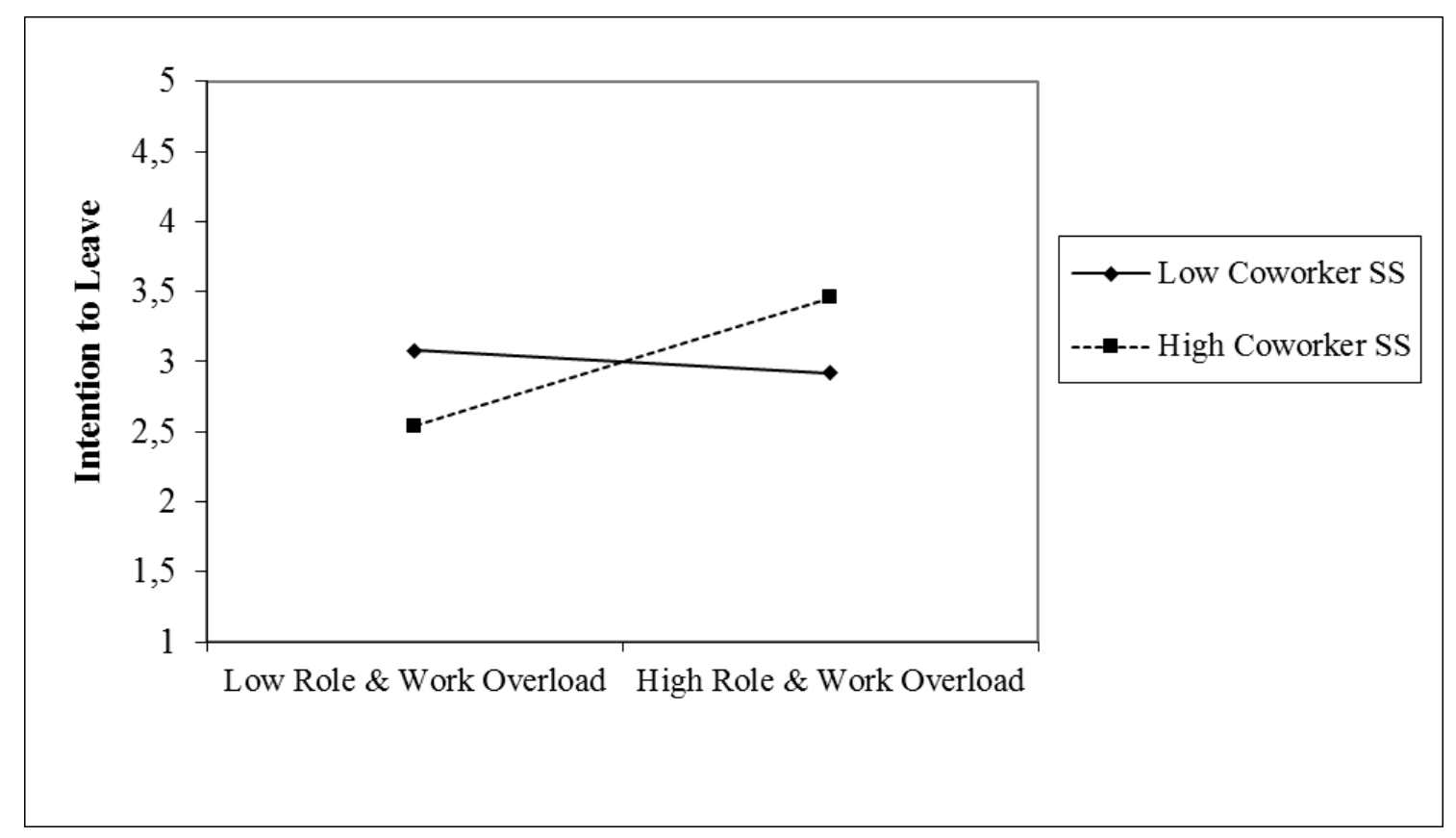

Figure 1c. The Significant Moderating Effect of Coworker Social Support on the Relationship b/w Role and Work Overload and Intention to Leave. 


\section{Discussion}

The main purpose of this study was to test the buffering effects of various sources of social support on the relationship between distinct job stressors and intention to leave. The findings suggest that supervisor support moderates the effects of role and work overload, and role insufficiency on intention to leave. Coworker support is indicated only to be a moderator for the relationship between role and work overload and intention to leave; yet, these moderations turn out to be reverse buffering effectsin contrast to our hypotheses. Although no such finding has been reported in the limited number of studies considering intention to leave, Bakker and Demerouti's (2007) suggestions might offer an explanation for these findings. According to their DemandResources Model, the reason why various support sources play a buffering role changes as a function of different types of job stressors. For example, when considering supervisor support, it can be both helpful and harmful: the appreciation and support can, on the one hand, be useful as it may help one cope better with job demands, while it can, on the other hand, implement an additional demand, indicating reverse buffering.

When focusing on general job stress literature, Rauktis and Koeske (1994) found that supervisor social support has a reverse buffering effect on the work overload and job satisfaction relationship. Correspondingly, Fenlason and Beehr (1994), investigating social support factors that influence the relationships between job stressors and strains, demonstrated that, whereas positive communication content from the supervisor is a buffer, negative communication content from coworkers inflates the adverse outcomes of job stress. Similarly, Kaufman and Beehr's study (1986) also reveals that support received from both the supervisor and from the coworkers has a reverse buffering role with respect to the effects on various strains of workload and role insufficiency. In their explanations of these findings, the authors claim that if supervisors are the source of stress, and, at the same time, themselves the source of support, then this support is likely to be appraised as stressful (see also Beehr, Farmer, Glazer, Gudanowski, \& Nair, 2003). For these employees, therefore, receiving social support may increase their perceived stress.

With respect to coworker support, Beehr et al. (2010) showed that supportive interactions with coworkers may increase the intention to leave a job. Clearly, it is not the mere presence but also the content of support received from the organization that matters: support that reinforces conversations and disclosure of negative aspects of the job can create a reverse buffering effect. This effect could even be more pronounced in the case of individuals who work in the same department, with negative sharing of stressors like workload. In cultures presenting high in-group collectivism, like Turkey (Kabasakal \& Dastmalchian, 2001), treating family and close coworkers as in-group may elevate negative communication by increasing social support. As the content in the support has not been considered in this study, the level of its operation on the findings is not clear. Consequently, future studies that investigate intention to leave in the job stress process should also take into account factors such as the content of the support and how it is perceived.

With respect to other stressor-strain relationships, our results revealed no buffering effects of social support. For organizational norms and practices, as well as insecure relationships, support received from either the supervisor or coworkers did not show a buffering effect; support received from coworkers showed no buffering effect in 
respect of role insufficiency. Supervisors are themselves integral to organizational norms and practices, and, as can be seen in Table 1, perceived support from the supervisor decreases with the increases in organizational norms and practices appraisal scores. A similar relational pattern was also observed in the insecure relationships factor for both supervisor and coworker support. Even though they are considered the main sources of support, it would appear that supervisors and coworkers may, conversely, cause a perception that the relationships are indeed insecure; or, to put it another way, the presence of support from these sources may not indicate a decrease in perceived stress in terms of these stressors since such a connection may actually hinder the moderating effects on the stressor-strain relationship of these support sources. Still, overall, insignificant results concerning buffering effects may connote the importance of a match between stressor and social support sources (Cohen \& Wills, 1985).

As expected, support received from out of work sources had no buffering function on the effect of any of the job stressors on intention to leave. The buffering effect of non-work support in the process of job stress has rarely been investigated. But in one study, Leather et al. (1998) demonstrated that, rather than the support received from out of work, it was support provided by the organization that reduces the negative effects of job stress. Nissly et al. (2005), too, reported that non-work support has no effect. As Cohen and Wills (1985) has emphasized, a buffering effect will appear only if specific stressors match with certain support sources. Leather et al. (1998) explain this finding by suggesting the possibility that only the perception of formal support from the organization can buffer the increased negative effects caused by exposure to workplace stressors. That major support coming from within the organization can lead to workrelated employee development, which in turn may enable employees to better cope with problems, may be the main reason for this. Also, it is probable that non-work support sources buffer the relationship between job stressors and individual strains rather than organizational outcomes. For instance, in one study, although family support was found to buffer burnout - a type of individual strain - support received from coworkers and supervisors did not reveal such an effect (Baruch-Feldman, Brondolo, Ben-Dayan, \& Schwartz, 2002). Therefore, support received from out of work cannot be assumed to buffer the stress-intention to leave relationship, which is a type of a work-related strain.

Finally, it is worth mentioning additional results regarding the main effects of job stressors on intention to leave. The findings revealed that all the job stressors, except for physical work demands, moderately predicted intention to leave. In other words, in line with many other studies in this area (Duraisingam et al., 2009; Gaither, Kahaleh, Doucette, Mott, Pederson, \& Schommer, 2008), it was found that those who experience higher stress tend to leave their jobs more. However, it is interesting that role and work overload, which is the most frequently investigated job stressor with respect to its effects on intention to leave (e.g., Gray \& Muramatsu, 2013), turned out to have the lowest predictive value in this study. On the other hand, the less highlighted stressor, role insufficiency (e.g., Rahim \& Psenicka, 1996), did predict intention to leave more highly than all the other relevant stressors. This may indicate that role insufficiency should be considered in more detail in further studies.

Regarding the limitations of this study, we should first address the characteristics of the sample with respect to limited size and employee type, consisting only of whitecollar employees. This was due to the permission received from a limited number of companies. One must be cautious when generalizing the findings to the whole 
population of white-collar employees. A similar study could be conducted with larger samples and blue-collar employees. Secondly, with its cross-sectional design, this study is prone to those criticisms of causality applied to other studies with a similar design. For this reason, further studies should be longitudinal in nature. Additionally, the job stressors measured in this study are subject to the restrictions of the instrument they have been used to measure. Still, that the scale used here is a tool developed in Turkey is an important aspect of this study.

Regarding the strengths of this study, it is one of the few studies to investigate the role of social support in the effects of job stressors on intention to leave. Furthermore, it tests various job stressors with different sources of social support all together, which is important since this showed that the moderating role of social support may vary for distinct job stressors. Notwithstanding these positive points, however, the most important aspect of the study is that, to the authors' knowledge, this is the first study in the area to illustrate a reverse buffering effect with respect to intention to leave.

Reflecting on these findings from the perspective of organizations, it can be concluded that, in order to hamper intention to leave, which is the most fundamental predictor of leaving a job, stressor reduction can be substantial if the direct effects are taken into account. With respect to reverse buffering effects, it is apparent that organizations tend to have limited control over support received from out of work, so it will probably be more efficacious to focus on support sources from within the organization. One of the steps that could be taken is to train supervisors and give them feedback in how to mentor their employees regarding the quality and type of social support. Correspondingly, special emphasis should be placed on increasing both the quality and the quantity of social support provided by coworkers.

\section{References}

Abdel-Halim, A. A. (1982). "Social support and managerial affective responses to job stress", Journal of Organizational Behavior, 3, 281-295.

Aiken, L. S., \& West, S. G. (1991). "Multiple Regression Testing and Interpreting Interactions”, Newbury Park, CA: Sage.

Allisey, A. F., Noblet, A. J., Lamontagne, A. D., \& Houdmont, J. (2013). “Testing a model of officer intentions to quit: The mediating effects of job stress and job satisfaction", Criminal Justice and Behavior, 20, 1-21.

Antón, C. (2009). “The impact of role stress on workers' behaviour through job satisfaction and organizational commitment", International Journal of Psychology, 44, 187-194.

Bakker, A. B., \& Demerouti, E. (2007). "The job demands-resources model: State of the art", Journal of Managerial Psychology, 22(3), 309-328.

Baruch-Feldman, C., Brondolo, E., Ben-Dayan, D., \& Schwartz, J. (2002). "Sources of social support and burnout, job satisfaction, and productivity", Journal of Occupational Health Psychology, 7, 84-93. 
Beehr, T. A. (1976). "Perceived situational moderators of the relationship between subjective role ambiguity and role strain", Journal of Applied Psychology, 61, $35-40$.

Beehr, T. A., Bowling, N. A., \& Bennett, M. M. (2010). "Occupational stress and failures of social support: When helping hurts", Journal of Occupational Health Psychology, 15, 45-59.

Beehr, T. A., Farmer, S. J., Glazer, S., Gudanowski, D. M., \& Nair, V. N. (2003). "The enigma of social support and occupational stress: Source congruence and gender role effects", Journal of Occupational Health Psychology, 8, 220.

Beehr, T. A., Jex, S. M., Stacy, B. A., \& Murray, M. A. (2000). "Work stressors and coworker support as predictors of individual strain and job performance", Journal of Organizational Behavior, 21, 391-405.

Çalışır, F., Gümüşsoy, C. A., \& Iskın, I. (2011). "Factors affecting intention to quit among IT professionals in Turkey", Personnel Review, 40(4), 514 - 533.

Carsten, J. M., \& Spector, P. E. (1987). "Unemployment, job satisfaction, and employee turnover: A meta-analytic test of the Muchinsky model", Journal of Applied Psychology, 72, 374-381.

Chiu, C. K., Chien, C. S., Lin, C. P., \& Hsiao, C. Y. (2005). "Understanding hospital employee job stress and turnover intentions in a practical setting: The moderating role of locus of control", Journal of Management Development, 24(10), 837-855.

Chiu, S. F., Yeh, T. P., \& Huang, T. C. (2015). "Role stressors and employee deviance: The moderating effect of social support", Personnel Review, 44(2), 308-324.

Cohen, S., \& Wills, T. A. (1985). "Stress, social support, and the buffering hypothesis", Psychological Bulletin, 98, 310-357.

Demerouti, E., Bakker, A. B., Nachreiner, F., \& Schaufeli, W. B. (2001). "The job demands-resources model of burnout", Journal of Applied Psychology, 86(3), 499-512.

Dormann, C., \& Zapf, D. (1999). "Social support, social stressors at work, and depressive symptoms: Testing for main and moderating effects with structural equations in a three-wave longitudinal study", Journal of Applied Psychology, 84, 874-884.

Duraisingam, V., Pidd, K., \& Roche, A. M. (2009). "The impact of work stress and job satisfaction on turnover intentions: A study of Australian specialist alcohol and other drug workers", Drugs: Education, Prevention, and Policy, 16(3), 217-231.

Fenlason, K. J., \& Beehr, T. A. (1994). "Social support and occupational stress: Effects of talking to others", Journal of Organizational Behavior, 15, 157-175.

Gaither, C. A., Kahaleh, A. A., Doucette, W. R., Mott, D. A., Pederson, C. A., \& Schommer, J. C. (2008). "A modified model of pharmacists' job stress: The role of organizational, extra-role, and individual factors on work-related outcomes", Research in Social and Administrative Pharmacy, 4, 231-243. 
Gray, J. A., \& Muramatsu, N. (2013). "When the job has lost its appeal: Intentions to quit among direct care workers", Journal of Intellectual and Developmental Disability, 38, 124-133.

Hellman, C. M. (1997). "Job satisfaction and intent to leave", The Journal of Social Psychology, 137(6), 677-689.

Huang, H. I. (2005). "Investigation of the fit among current and preferred organizational cultures, personality styles, and job attitudes in employees of international tourist hotels in Taiwan", Unpublished doctoral dissertation, Idaho State University, USA.

Hurrell, J. J., JR., Nelson, D. L., \& Simmons, B. L. (1998). "Measuring job stressors and strains: Where we have been, where we are, and where we need to go", Journal of Occupational Health Psychology, 3, 368-389.

Ismail, A., Suhaimi, F. F., Bakar, R. A., \& Alam, S. S. (2013). "Job stress with supervisor's social support as a determinant of work intrusion on family conflict", Journal of Industrial Engineering and Management, 6, 1188-1209.

Jamal, M. (2005). "Personal and organizational outcomes related to job stress and Type-A behavior: A study of Canadian and Chinese employees", Stress and Health, 21, 129-137.

Jamal, M. (2007). "Job stress and job performance controversy revisited: An empirical examination in two countries", International Journal of Stress Management, 14, 175-187.

Jamal, M. (2013). "Job Stress among hospital employees in Middle East: Social support and Type A behaviour as moderators", Middle East Journal of Business, 8(3), $7-17$.

Johnson, J. V., \& Hall, E. M. (1988). "Job strain, work place social support, and cardiovascular disease: a cross-sectional study of a random sample of the Swedish working population", American Journal of Public Health, 78(10), 1336-1342.

Jou, R. C., Kuo, C. W., \& Tang, M. L. (2013). “A study of job stress and turnover tendency among air traffic controllers: The mediating effects of job satisfaction", Transportation Research Part E: Logistics and Transportation Review, 57, 95-104.

Kabasakal, H., \& Dastmalchian, A. (2001). "Introduction to the special issue on leadership and culture in the Middle East", Applied Psychology: An International Review, 50(4), 479-488.

Karasek, R. A. (1979). "Job demands, job decision latitude and mental strain: Implications for job redesign", Administrative Science Quarterly, 24, 285308.

Kaufmann, G. M., \& Beehr, T. A. (1986). "Interactions between job stressors and social support: Some counterintuitive results", Journal of Applied Psychology, 71, 522-526. 
Kim, H., \& Stoner, M. (2008). "Burnout and turnover intention among social workers: Effects of role stress, job autonomy and social support", Administration in Social Work, 32, 5-25.

Klassen, R. M., \& Chiu, M. M. (2011). “The occupational commitment and intention to quit of practicing and pre-service teachers: Influence of self-efficacy, job stress, and teaching context", Contemporary Educational Psychology, 36, 114-129.

Ko, J. W., \& Yom, Y. H. (2003). "The role of social support in the relationship between job stress and job satisfaction/organizational commitment", Taehan Kanho Hakhoe Chi, 33(2), 265-274.

Larocco, J. M., House, J. S., \& French JR, J. R. (1980). “Social support, occupational stress, and health", Journal of Health and Social Behavior, 21(3), 202-218.

Lazarus, R. S. (1991). "Progress on a cognitive-motivational-relational theory of emotion", American Psychologist, 46, 819-834.

Leather, P., Lawrence, C., Beale, D., Cox, T., \& Dickson, R. (1998). "Exposure to occupational violence and the buffering effects of intra-organizational support", Work \& Stress, 12, 161-178.

Leong, C. S., Furnham, A., \& Cooper, C. L. (1996). "The moderating effect of organizational commitment on the occupational stress outcome relationship", Human Relations, 49, 1345-1363.

Michaels, C. E., \& Spector, P. E. (1982). "Causes of employee turnover: A test of the Mobley, Griffeth, Hand, and Meglino model", Journal of Applied Psychology, 67, 53-59.

Mobley , W. H. (1977). "Intermediate linkages in the relationship between job satisfaction and employee turnover", Journal of Applied Psychology, 62, 237240.

Mobley, W. H., Griffeth, R. W., Hand, H. H., \& Meglino, B. M. (1979). "Review and conceptual analysis of the employee turnover process", Psychological Bulletin, 86, 493-522.

Netemeyer, R. G., Johnston, M. W., \& Burton, S. (1990)^. "Analysis of role conflict and role ambiguity in a structural equations framework", Journal of Applied Psychology, 75, 148-157.

Nissly, J. A., Mor Barak, M. E., \& Levin, A. (2005). "Stress, social support, and workers' intentions to leave their jobs in public child welfare", Administration in Social Work, 29, 79-100.

Özalp Türetgen, I., Sertel Berk, Ö., Basbug, G., \& Unsal, P. (2012). "The development of the job stressor appraisal scale as part of the job stress battery", European Journal of Psychological Assessment, 28(2), 147-153.

Parkes, K. R., Mendham, C. A., \& Von Rabenau, C. (1994). "Social support and the demand-discretion model of job stress: Tests of additive and interactive effects in two samples", Journal of Vocational Behavior, 44, 91-113. 
Podsakoff, P. M., Mackenzie, S. B., \& Podsakoff, N. P. (2012). "Sources of method bias in social science research and recommendations on how to control it", Annual Review of Psychology, 65, 539-569.

Pomaki, G., Delongis, A., Frey, D., Short, K., \& Woehrle, T. (2010). "When the going gets tough: Direct, buffering and indirect effects of social support on turnover intention", Teaching and Teacher Education, 26, 1340-1346.

Rahim, M. A. (1997). "Relationships of stress, locus of control, and social support to psychiatric symptoms and propensity to leave a job: A field study with managers", Journal of Business and Psychology, 12, 159-174.

Rahim, M. A., \& Psenicka, C. (1996). “A structural equations model of stress, locus of control, social support, psychiatric symptoms, and propensity to leave a job”, The Journal of Social Psychology, 136(1), 69-84.

Rasch, R. H., \& Harrell, A. (1989), "The impact of individual differences on MAS personnel satisfaction and turnover intentions", Journal of Information Systems, 4(1), 13-22.

Rauktis, M. E., \& Koeske, G. F. (1994). "Maintaining social worker morale: When supportive supervision is not enough", Administration in Social Work, 18, 39-60.

Reininghaus, U., Craig, T., Gournay, K., Hopkinson, P., \& Carson, J. (2007). "The High Secure Psychiatric Hospitals' Nursing Staff Stress Survey 3: Identifying stress resistance resources in the stress process of physical assault", Personality and Individual Differences, 42, 397-408.

Schreurs, B. H., Hetty Van Emmerik, I. J., Günter, H., \& Germeys, F. (2012). "A weekly diary study on the buffering role of social support in the relationship between job insecurity and employee performance", Human Resource Management, 51, 259-279.

Sertel Berk, H. Ö., Özalp Türetgen, I., Ünsal, P., \& Başbuğ, G. (2010a). "İş Stresi Bataryası: Bazı Biçimlendirici Değişkenler ve Stres Belirtileri Ölçekleri", 16. Ulusal Psikoloji Kongresi'nde sunulmuş sözlü bildiri, 14-17 Nisan, Mersin Üniversitesi, Mersin.

Sertel Berk, H. Ö., Özalp Türetgen, I., Ünsal, P., Basbug, G. (2010b). "Job Stress Battery: Scales of Job Control and Occupational Outcome Variables", 9th Conference of the European Academy of Occupational Health Psychology'de sunulmuş poster, 29-31 Mart, Roma, İtalya.

Shader, K., Broome, M. E., Broome, C. D., West, M. E., \& Nash, M. (2001). "Factors influencing satisfaction and anticipated turnover for nurses in an academic medical center", Journal of Nursing Administration, 31(4), 210-216.

Siegrist, J. (1996). "Adverse health effects of high-effort/low-reward conditions", Journal of Occupational Health Psychology, 1(1), 27-41.

Simmons, C., Cochran, J. K., \& Blount, W. R. (1997). "The effects of job-related stress and job satisfaction on probation officers' inclinations to quit", American Journal of Criminal Justice, 21, 213-229. 
Siu, O. L., Cooper, C. L., \& Donald, I. (1997). “Occupational stress, job satisfaction and mental health among employees of an acquired TV company in Hong Kong", Stress Medicine, 13, 99-107.

Terry, D. J., Nielsen, M., \& Perchard, L. (1993). "Effects of work stress on psychological well-being and job satisfaction: The stress-buffering role of social support", Australian Journal of Psychology, 45, 168-175.

Thoits, P. A. (1982). "Conceptual, methodological, and theoretical problems in studying social support as a buffer against life stress", Journal of Health and Social Behavior, 23, 145-159.

Vagg, P. R., \& Spielberger, C. D. (1999). "The Job Stress Survey: Assessing perceived severity and frequency of occurrence of generic sources of stress in the workplace”, Journal of Occupational Health Psychology, 4, 288-292.

Vermeulen, M., \& Mustard, C. (2000). "Gender differences in job strain, social support at work, and psychological distress", Journal of Occupational Health Psychology, 5, 428-440.

Viswesvaran, C., Sanchez, J. I., \& Fisher, J. (1999). "The role of social support in the process of work stress: A meta-analysis", Journal of Vocational Behavior, 54, 314-334. 